\title{
Analisis Faktor Penggunaan Dompet Digital Di Kalangan Mahasiswa Perguruan Tinggi Surabaya
}

\author{
Vina Dewi Ramadhanty*1, Rafi Indra Permana ${ }^{2}$, Belia Rida Syifa Fauzia ${ }^{3}$, Nur Aini \\ Rakhmawati $^{4}$ \\ ${ }^{1,2}$ Institut Teknologi Sepuluh Nopember; Jl. Raya ITS, Keputih, Surabaya, Kota SBY, Jawa \\ Timur, 60117, (031) 5994251 \\ ${ }^{3}$ Departemen Sistem Informasi, FTEIC ITS, Surabaya \\ e-mail: *11 vinadewi16@gmail.com, ${ }^{2}$ rafiindraper@gmail.com, \\ ${ }^{3}$ beliaridasyifafauzia@gmail.com, ${ }^{4}$ nur.aini@ is.its.ac.id
}

\begin{abstract}
Abstrak
Pada masa kini perkembangan teknologi terjadi dengan sangat pesat. Seluruh bidang dalam kehidupan turut berkembang mengikuti perkembangan teknologi. Salah satu bidang yang berkembang dengan pesat dan menarik banyak perhatian kalangan adalah bidang keuangan. Salah satu perkembangan teknologi di bidang keuangan atau yang biasa disebut dengan Financial Technology meliputi dompet digital. Dompet digital banyak digunakan oleh seluruh lapisan masyarakat termasuk mahasiswa. Penelitian ini dilakukan untuk mengetahui faktor faktor penggunaan dompet digital di kalangan mahasiswa. Penelitian ini dilakukan dengan menyebar kuesioner kepada mahasiswa perguruan tinggi di Surabaya. Hasil dari kuesioner tersebut diolah dengan menggunakan statistika deskriptif dan diambil kesimpulan dari data tersebut. Hasil yang didapatkan dari penelitian ini adalah mahasiswa setuju dengan berbagai faktor penggunaan dompet digital yang telah disebutkan oleh peneliti pada kuesioner.
\end{abstract}

Kata kunci- Financial Technology, Dompet Digital, Statistika Deskriptif

\begin{abstract}
Nowadays, technological developments occur very rapidly. All areas of life also develop following technological developments. One of the areas that is growing rapidly and attracting a lot of attention is the financial area. One of the technological developments in finance or what is commonly referred to as Financial Technology incudes digital wallets. Digital Wallets are widely used by all levels of society, including students. This research was conducted to determine the factors of the use of digital wallets among students. This research was conducted by distributing questionnaires to college students in Surabaya. The results of the questionnaire were processed using descriptive statistics and conclusions were drawn from the data. The results obtained from this study are that students agree with the various factors of using digital wallets that have been mentioned by researchers in the questionnaire.
\end{abstract}

Keywords - Financial Technology, Digital Wallets, Descriptive Statistics 


\section{PENDAHULUAN}

Perkembangan teknologi terjadi dengan sangat pesat pada masa kini. Hampir seluruh bidang juga berkembang menyesuaikan dengan perkembangan teknologi. Salah satu bidang yang turut berkembang dengan adanya perkembangan teknologi adalah bidang keuangan. Perkembangan teknologi di bidang keuangan atau biasa disebut financial technology adalah inovasi bidang financial yang berfokus pada teknologi modern ( Rakhmat Dwi P; 2019, 1). Menurut Bank Indonesia, financial technology adalah penggunaan teknologi dalam sistem keuangan yang menghasilkan produk, layanan, teknologi, dan / atau model bisnis baru, serta dapat berdampak pada stabilitas moneter, stabilitas sistem keuangan, dan / atau efisiensi, kelancaran, keamanan, dan keandalan sistem pembayaran. Singkatnya, financial technology adalah pemanfaatan teknologi di bidang keuangan untuk memberikan pelayanan dalam pembayaran ( Risya dan Estro ; 2019,2 ). Financial technology sendiri terbagi menjadi beberapa kategori yaitu peer - to - peer lending dan crowdfunding, market aggregator, manajemen risiko dan investasi, payment, clearing, and settlement ( Rakhmat Dwi P. ; 2019,[1,3]). Hampir seluruh lapisan masyarakat sangat terbantu dengan adanya financial technology. Salah satu financial technology yang berkembang pesat adalah dompet digital ( Agus Kusnawan et al ; 2019 , 4). Mahasiswa adalah salah satu pengguna dari kenyamanan teknologi yang ditawarkan oleh dompet digital ( Rofiah dan Setiyadi ; 2020,5 ). Mahasiswa dengan kesibukan yang sangat tinggi tentunya tertarik dengan kenyamanan dan kemudahan yang ditawarkan oleh dompet digital ( Irna dan Intan ; 2020,6 ). Mahasiswa dapat membayar makanan, membayar biaya tranportasi, membayar webinar dan lain sebagainya secara mudah. Hanya dengan scan barcode atau transfer maka mahasiswa dapat melakukan pembayaran tersebut dimana saja dan kapanpun ( Atriani ; 2020,7 ). Oleh karena itu, penelitian ini dilakukan dengan tujuan untuk mengetahui apakah mahasiswa setuju atau tidak dalam penggunaan dompet digital dan alasan mengapa mahasiswa setuju atau tidak terhadap penggunaan dompet digital. Dengan hasil penelitian tersebut, dapat dianalisa faktor - faktor yang mendukung penggunaan dompet digital oleh mahasiswa.

\subsection{Kajian Pustaka}

\section{METODE PENELITIAN}

\subsubsection{Financial Technology}

Sebuah inovasi berhasil mentransformasi suatu system atau pasar yang eksisting, dengan memperkenalkan kepraktisan, kemudahan akses, kenyamanan, dan biaya yang ekonomis, dikenal sebagai Inovasi Disruptif ( Disruptive Innovation ). Inovasi disruptif ini biasanya mengambil segmen pasar tertentu yang kurang diminati atau dianggap kurang penting bagi penguasa pasar, namun inovasinya bersifat breakthrough dan mampu meredefinisi system atau pasar yang eksisting. Fenomena Inovasi Disruptif ini juga terjadi di Industri Jasa Keuangan yang telah mendisrupsi landscape Industri Jasa Keuangan secara global mulai dari struktur industrinya, teknologi intermediasinya, hingga model pemasarannya kepada konsumen. Keseluruhan perubahan ini mendorong munculnya fenomena baru yang disebut Financial Technology ( Fintech ) ( Muliaman D. Hadad ; 2017,8 ).

\subsubsection{Dompet digital}

Beberapa penelitian mengenai dompet digital menyebutkan definisi dompet digital sebagai uang yang transaksi pembayarannya dilakukan melalui telepon genggam dan dengan terhubung jaringan internet. Menurut Shukla dan Malhotra (2019), "Dompet ponsel setara dengan dompet fisik, dompet ponsel menyediakan penggunanya untuk menyimpan uang seperti

\footnotetext{
Vina, et.,al (Analisis Faktor Penggunaan Dompet Digital Di Kalangan Mahasiswa Perguruan Tinggi Surabaya)
} 
pada akun bank yaitu pengguna harus membuat akun dengan penyedia dompet ponsel, uang dapat dimasukan dalam akun dompet ponsel menggunakan kartu debet, kartu kredit, akun bank, dan sebagainya". Sementara, dikutip dari Sagayarani (2017), "Pembayaran digital adalah cara pembayaran menggunakan mode digital. Dalam pembayaran digital, pembayar dan penerima bayaran keduanya menggunakan mode digital untuk mengirim dan menerima uang. Disebut juga pembayaran elektronik. Tidak ada uang tunai yang diikutkan dalam pembayaran digital. Semua transaksi pada pembayaran digital dilakukan secara online. Itu merupakan sebuah cara yang instan dan mudah untuk melakukan pembayaran.” ( Sulistyowati, Paais, \& Rina; 2020, 9)

\subsubsection{Statistika Deskriptif}

Statistika deskriptif adalah cabang statistika yang digunakan untuk menjelaskan, menerangkan dan mendeskripsikan suatu keadaan ( Paul Suparno ; 2017,10 ). Secara lebih singkat, statistika deskriptif adalah cabang statistika yang memudahkan sesorang membaca informasi data tersebut ( Maysani dan Pujiastuti ; 2020,11 ). Statistika deskriptif ditampilkan melalui grafik, table, diagram ataupun pictogram yang memuat perhitungan mean, median, modus ataupun analisis sebaran data menurut perhitungan presentasi dan standar deviasi.

(Athoillah et al ; 2020,12)

\subsection{Metodologi}

Penelitian ini akan berfokus pada penggunaan dompet digital di kalangan mahasiswa Surabaya. Data mentah dikumpulkan melalui kuesioner dengan cara online. Dengan tujuan untuk mencari data reponden mahasiswa perguruan tinggi Surabaya. Kuesioner online disebar di berbagai group sosial media dengan responden yang berbeda tipe seperti wa, line, dan sebagainya. Pengumpulan data kuesioner dilakukan dalam waktu satu minggu, dengan 84 responden yang dapat digunakan. Data yang dikumpulkan merupakan data kuantitatif yang dimana hasil data akan di analisis lebih lanjut dengan menggunakan statistik deskiriptif atau merupakan metode - metode yang juga berkaitan dengan pengumpulan dan penyajian suatu gugus data sehingga dapat memberikan informasi yang berguna. Hasil dari kuesioner tersebut cukup signifikan dan terdapat alur dari metodologi pengerjaan penelitian ini dapat dilihat dari gambar 1.

\subsubsection{Studi Literatur}

Pada penelitian ini, langkah awal yang dilakukan penulis yaitu Studi Literatur. Yang dimana melakukan mapping fitur pertanyaan atau pemetaan pada fitur pertanyaan yang akan digunakan. Pemetaan tersebut berkaitan berdasarkan usia, jenis kelamin, perguruan tinggi, tingkatan semester, pemasukan dalam 1 bulan, pernah atau tidaknya bertransaksi menggunakan dompet digital, jumlah bertransaksi dalam 1 bulan, nama dompet digital yang digunakan, dan jumlah pemakaian dompet digital yang digunakan maupun dompet digital yang tidak digunakan. Dengan adanya pemetaan fitur tersebut mempermudah berjalannya alur yang akan digunakan pada metodologi kuesioner penelitian. 


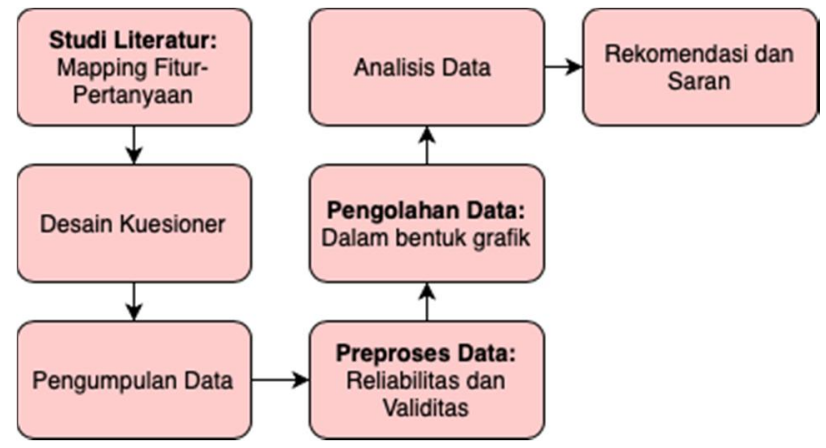

Gambar 1. Metodologi Penelitian

\subsubsection{Pengumpulan Data}

Sampel dari riset ini adalah mahasiswa perguruan tinggi yang berada di kota Surabaya mulai dari umur dibawah atau sama dengan 18 tahun sampai dengan usia 23-24 tahun dan yang telah menggunakan atau tidak pernah menggunakan dompet digital. Untuk mendapatkan kesimpulan yang dapat dipertanggung jawabkan, maka jumlah minimum sampel yang reliabel dan valid harus terpenuhi.

\subsubsection{Preproses Data}

Pada tahap ini terjadinya reliabilitas dan validitas data, yang dimana meng- cleaning data yang seharusnya terisi namun kosong. Sehingga dapat tersebut valid dan dapat digunakan dalam penelitian.

\subsubsection{Pengolahan Data}

Dalam penelitian yang dilakukan penulis, pengolahan data yang dilakukan adalah dengan cara statistik deskriptif atau metode-metode yang berkaitan dengan pengumpulan dan penyajian suatu gugus data sehingga memberikan informasi yang berguna. Tujuan dari penggunakan statistika deskriptif yaitu dengan hasil responden yang berupa grafik dan data yang diperolah cukup banyak sehingga dengan menggunakan statistika deskriptif dapat membantu kita untuk menyederhanakan data dalam jumlah besar dengan cara yang logis. Data yang banyak direduksi dan diringkas sehingga lebih sederhana dan lebih mudah diinterpretasi. Pengolahan data dilakukan dari hasil data responden kuesioner dalam bentuk grafik berdasarkan kategorikategori yang telah ditetapkan penulis dan memperoleh hasil akhir dengan menggunakan cara menggunakan statistik deskriptif.

\subsubsection{Analisis Data}

Analisis data adalah sebuah proses untuk memeriksa, membersihkan, mengubah, dan membuat pemodelan data dengan maksud untuk menemukan informasi yang bermanfaat sehingga dapat memberikan petunjuk bagi peneliti untuk mengambil keputusan terhadap pertanyaan-pertanyaan penelitian. Dalam penelitian ini analisis data dilakukkan untuk mengetahui tanggapan seperti setuju atau tidaknya dengan adanya penggunaan dompet digital berdasarkan kategori yang telah ditetapkan.

\subsubsection{Rekomendasi dan Saran}

Alur terakhir yang terdapat pada metodologi penelitian adalah melakukan rekomendasi dan saran penelitian selanjutnya terkait faktor penggunaan dompet digital.

\section{HASIL DAN PEMBAHASAN}

Responden paling banyak didominasi pada rentang usia 19 - 20 tahun. Sebanyak $51,80 \%$ dari total responden memiliki rentang usia 19 - 20 tahun (Gambar 2). Lalu diikuti

\footnotetext{
Vina, et.,al (Analisis Faktor Penggunaan Dompet Digital Di Kalangan Mahasiswa Perguruan Tinggi Surabaya)
} 
rentang usia 21-22 tahun sebanyak 26,50\%, di bawah atau sama dengan 18 tahun sebanyak $15,66 \%$, dan yang paling sedikit adalah rentang usia 23-24 tahun dengan angka 6,02\%.

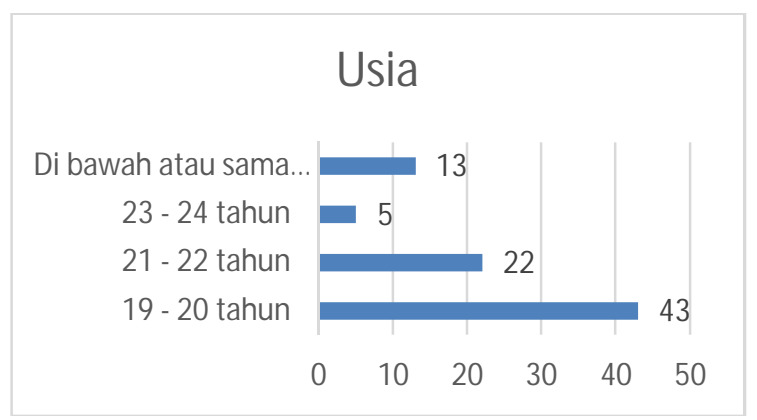

Gambar 2. Usia

Mayoritas responden dalam penelitian ini adalah perempuan dengan persentase sebanyak 51,80\%. Sedangkan laki-laki hanya sebesar 48,20\% (Gambar 3).

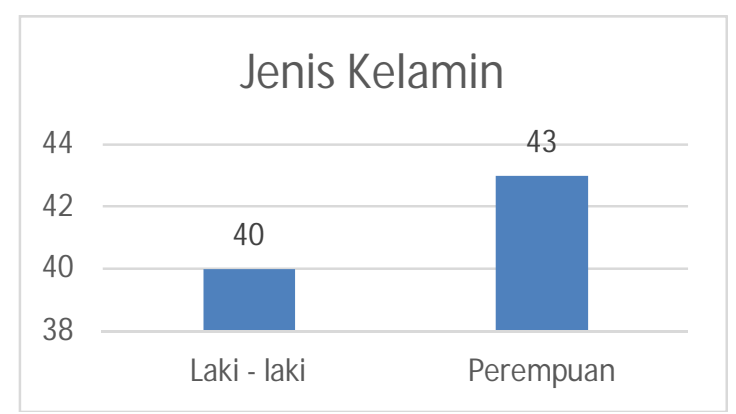

Gambar 3. Gender

Responden yang mendominasi merupakan mahasiswa Institut Teknologi Sepuluh Nopember dengan persentase 73,49\% (Gambar 4). Kemudian disusul UNAIR dan PENS yang masing-masing di angka 7,23\%. Lalu, untuk UPN, UBAYA, Hang Tuah, dan UNESA masing masing 2,41\%. Dan yang terakhir, untuk PPNS dan UWM masing-masing 1,20\%.

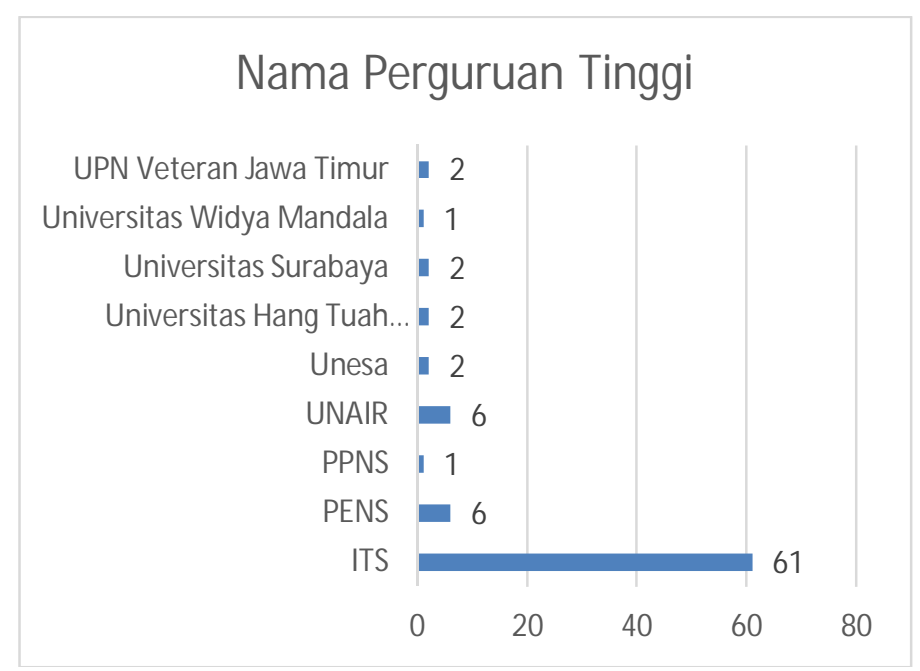

Gambar 4. Perguruan Tinggi 
Mayoritas responden menggunakan dompet digital dengan persentase sebesar 95,18\% (Gambar 5). Sedangkan untuk yang menjawab tidak menggunakan dompet digital hanya sebesar $4,82 \%$ dari total responden.

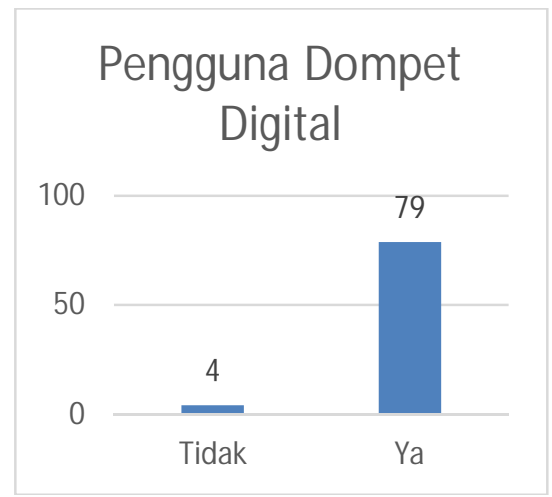

Gambar 5. Pengguna Dompet Digital

Gambar - gambar dibawah ini adalah gambar yang memuat jawaban responden atas faktor - faktor penggunaan dompet digital. Dari hasil kuesioner, mayoritas responden setuju dengan keamanan dompet digital. Ini ditunjukkan dengan persentase responden yang menjawab setuju sebesar 40,96\% (Gambar 6). Kemudian sebesar 34,94\% menjawab sangat setuju dengan keamanan dompet digital, disusul oleh jawaban netral sebesar $9,64 \%$ dan hanya ada satu responden yang menjawab tidak setuju dengan persentase sebesar $1,20 \%$.

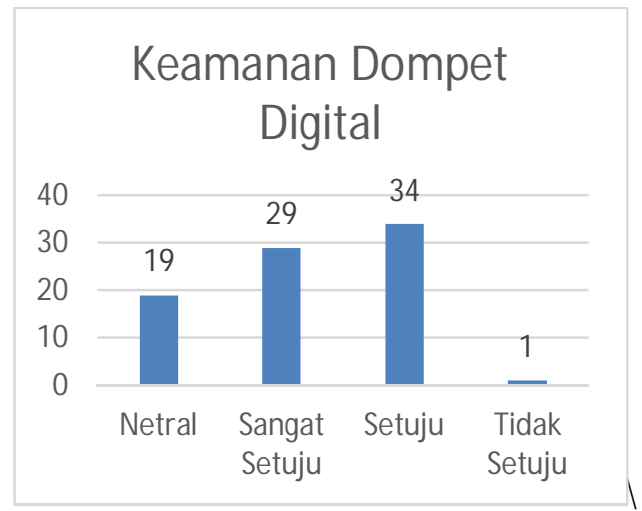

Gambar 6. Keamanan Dompet Digital

Dari hasil kuesioner didapatkan persentase yang cukup besar yaitu sebanyak 57,83\% untuk responden yang sangat setuju dengan faktor penggunaan dompet digital karena dompet digital mudah untuk digunakan dan didapatkan persentase $31,32 \%$ responden yang memilih setuju (Gambar 7). Untuk responden yang memilih netral memiliki persentase sebesar $9.63 \%$. Sedangkan, responden yang memilih tidak setuju sangatlah sedikit yaitu dengan persentase sebesar $1,2 \%$. 


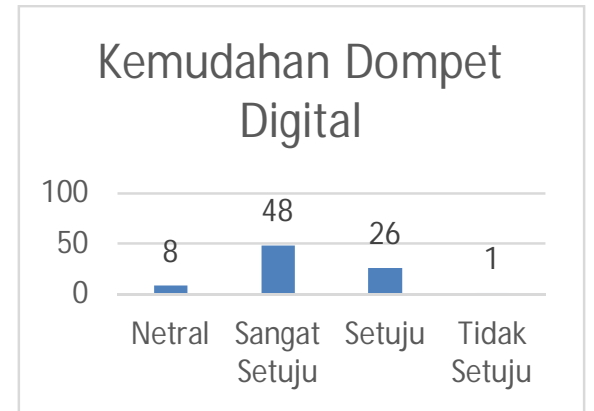

Gambar 7. Kemudahan Dompet Digital

Dari hasil kuesioner didapatkan persentase yang cukup besar yaitu sebanyak 60,24\% untuk responden yang sangat setuju dan didapatkan persentase sebesar 22,89\% untuk responden yang setuju dengan faktor penggunaan dompet digital karena mendapatkan promo seperti diskon dan cashback (Gambar 8). Responden yang memilih netral memiliki persentase sebesar $12,04 \%$. Hanya sebagian kecil responden yang memilih tidak setuju dan sangat tidak setuju yaitu dengan persentase sebesar $3,61 \%$ dan $1,20 \%$.

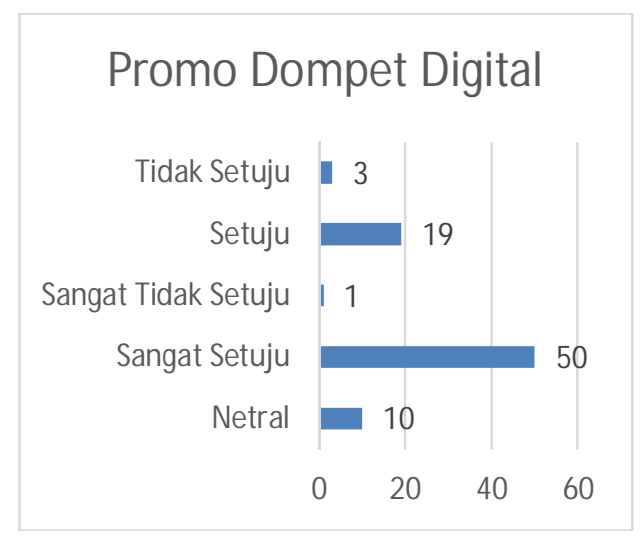

Gambar 8. Promo Dompet Digital

Dari hasil kuesioner didapatkan persentase yang paling besar untuk responden yang setuju dengan faktor penggunaan dompet digital karena tidak dikenai biaya admin yaitu sebesar $31,32 \%$ (Gambar 9). Persentase responden yang paling besar kedua diduduki oleh responden yang memilih netral yaitu sebesar $24,09 \%$. Selanjutnya, terdapat responden yang sangat setuju dengan persentase sebesar 22,89\%. Didapatkan pula persentase yang cukup besar untuk responden yang tidak setuju yaitu sebesar $16,86 \%$ dan responden yang sangat tidak setuju sebesar $4,81 \%$.

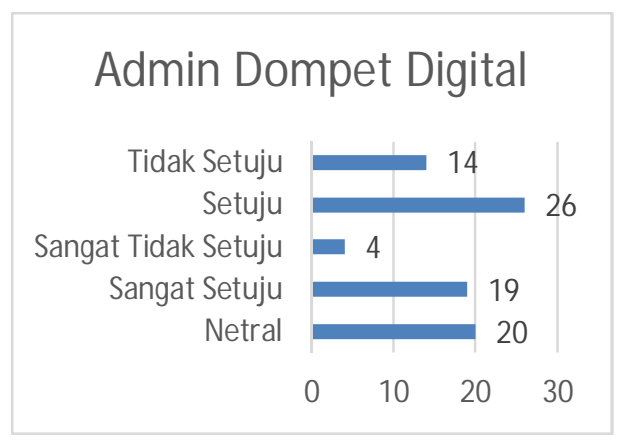

Gambar 9. Admin Dompet Digital 
Dari hasil kuesioner didapatkan persentase sebanyak 39,75\% untuk responden yang sangat setuju dengan faktor penggunaan dompet digital karena mengikuti perkembangan teknologi dan didapatkan persentase $31,32 \%$ responden yang memilih setuju (Gambar 10). Untuk responden yang memilih netral memiliki persentase cukup besar yaitu 25,30\%. Sedangkan, responden yang memilih tidak setuju dan sangat tidak setuju memiliki persentase sebesar $2,4 \%$ dan $1,2 \%$.

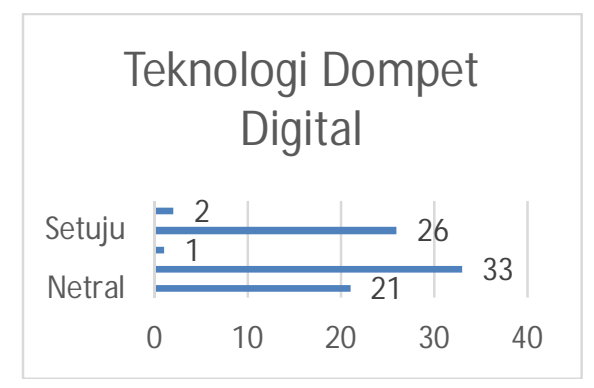

Gambar 10. Teknologi Dompet Digital

Responden merasa sangat setuju dengan dompet digital yang lebih praktis dan efisien dibandingkan uang tunai. Persentase responden yang sangat setuju sebesar $84,09 \%$, responden yang setuju sebesar 30,12\% (Gambar 11). Sisanya, responden merasa netral dengan persentase sebesar $12,04 \%$, responden yang merasa tidak setuju sebesar $1,2 \%$ dan sangat tidak setuju sebesar $2,4 \%$.

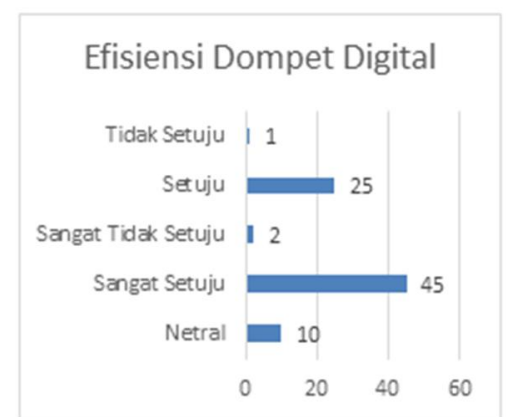

Gambar 11. Efisiensi Dompet Digital

Terdapat sebanyak 48,19\% sangat setuju dan 30,12\% setuju dengan privasi yang ditawarkan dari dompet digital (Gambar 12). Hal ini menandakan bahwa responden yaitu mahasiswa senang dengan privasi dari dompet digital seperti memasukkan password sebelum transaksi dengan dompet digital dilakukan. Sisanya, responden merasa netral dengan privasi tersebut dengan persentase sebesar $12,04 \%$. Responden juga merasa tidak setuju dan sangat tidak setuju terhadap privasi dompet digital dengan persentase sebesar $2,4 \%$ dan $1,2 \%$

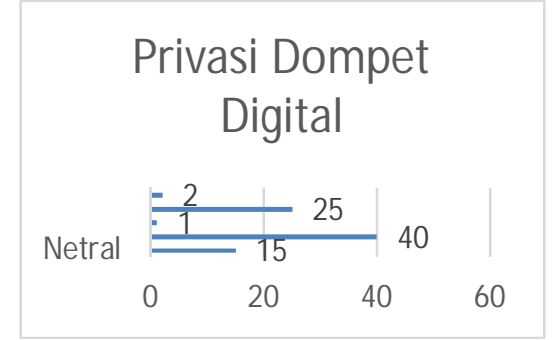

Gambar 12. Privasi Dompet Digital 
Terdapat sebanyak $40.96 \%$ dari seluruh total responden yang sangat setuju bahwa dompet digital memberikan security untuk para penggunanya (Gambar 13). Posisi kedua diduduki oleh responden yang setuju dengan security tersebut dengan persentase sebanyak $27.34 \%$. Selanjutnya, responden merasa netral dengan security tersebut dengan persentase sebesar $15.66 \%$. Sisanya, responden mengisi dengan tidak setuju dengan persentase sebesar $4.81 \%$ dan responden mengisi sangat tidak setuju dengan persentase sebesar $1.2 \%$.

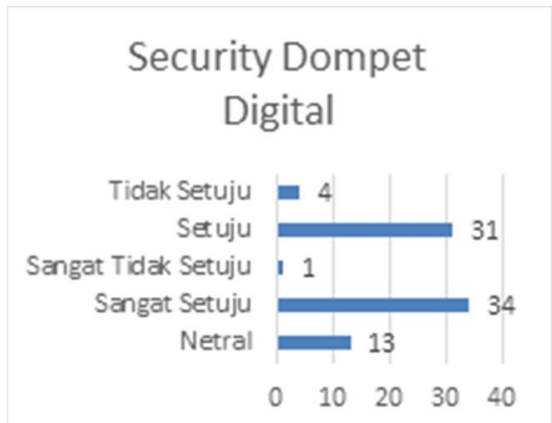

Gambar 13. Security Dompet Digital

Responden setuju dengan alasan penggunaan dompet digital karena dompet digital memiliki inovasi yang menarik (Gambar 14). Hal tersebut terbukti dengan angka persentase sebesar $40.96 \%$ untuk responden yang menyatakan setuju dan $40.96 \%$ responden menyatakan sangat setuju. Sisanya, responden menyatakan netral dengan persentase sebesar $15.67 \%$, menyatakan tidak setuju dengan persentase $1.2 \%$ dan sangat tidak setuju dengan persentase sebesar $1.2 \%$.

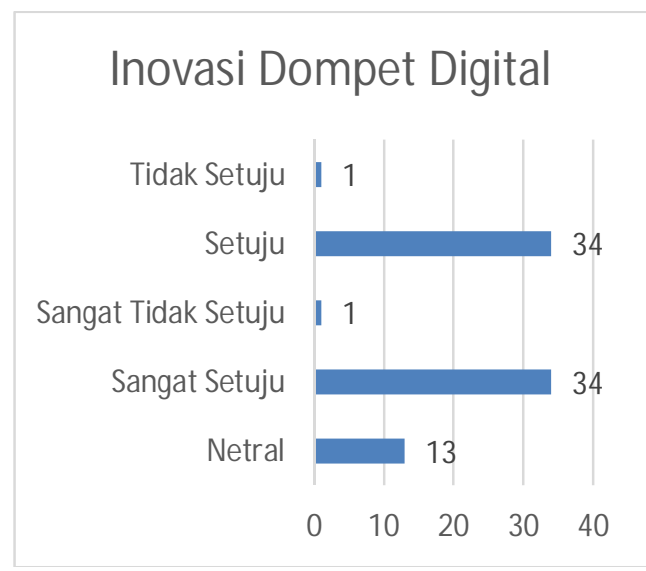

Gambar 14. Inovasi Dompet Digital

\section{KESIMPULAN}

Dari penelitian ini menunjukkan bahwa pengguna dompet digital lebih banyak berasal dari kalangan perempuan dengan rentang umur 19-20 tahun. Selain itu, dari hasil penelitian ini didapatkan bahwa pengguna dompet digital ITS cukup banyak di Institut Teknologi Sepuluh Nopember. Dari seluruh responden penelitian ini, 95\% responden merupakan pengguna dompet digital. Hal ini menunjukkan bahwa dompet digital sudah popular di kalangan mahasiswa dan banyak digunakan untuk kegiatan transaksi harian oleh mahasiswa. Dari penelitian ini dapat ditunjukkan bahwa alasan atau faktor penggunaan dompet digital adalah karena lebih aman 
dibandingkan dengan uang tunai, mudah digunakan, sering mendapatkan promo saat transaksi, tanpa dikenai biaya admin, sesuai dengan perkembangan teknologi, praktis dan efisien, menawarkan security dan privacy, dan memiliki inovasi yang berkembang didalamnya. Dari seluruh alasan atau faktor penggunaan dompet digital yang paling banyak disetujui adalah praktis dan efisien. Hal ini menunjukkan dompet digital sangat membantu transaksi mahasiswa dan mahasiswa merasa lebih praktis serta efisien untuk menggunakan dompet digital daripada uang tunai.

\section{SARAN}

Penulis menyadari bahwa ada keterbatasan dalam penelitian ini khususnya terkait jangkauan topik penelitian ini. Dengan demikian, diharapkan dapat dilakukan penelitian lanjutan dengan jangkauan yang lebih luas sehingga dapat diketahui lebih banyak lagi faktor faktor lain penggunaan dompet digital.

\section{UCAPAN TERIMA KASIH}

Penulis mengucapkan terima kasih kepada Ibu Nur Aini Rakhmawati selaku pembimbing dalam penelitian dan pembuatan paper ini sehingga paper ini dapat selesai dan topik yang diteliti yaitu faktor penggunaan dompet digital pada kalangan mahasiswa dapat diketahui.

\section{DAFTAR PUSTAKA}

[1] Pambudi, R. D. 2019, Perkembangan Fintech Di Kalangan Mahasiswa UIN, Harmony, No.4, Vol.2, 75-77, :https://journal.unnes.ac.id/sju/index.php/harmony/article/view/36456/15100.

[2] Nurrohyani, R., Sihaloho, E. D. 2020, Pengaruh Promosi Cashback pada OVO dan Go Pay Terhadap Perilaku Konsumen Mahasiswa Fakultas Ekonomi dan Bisnis Universitas Padjadjaran, EKONOMIKAWAN: Jurnal Ilmu Ekonomi dan Studi Pembangunan, No.1, Vol.20, :https://www.researchgate.net/profile/Estro_Dariatno_Sihaloho/publication/342586792_P engaruh_Promosi_Cashback_pada_OVO_dan_GoPay_Terhadap_Perilaku_Konsumen_M ahasiswa_Fakultas_Ekonomi_dan_Bisnis_Universitas_Padjadjaran/links/5efbf67d299bf1 8816f5ffc5/Pengaruh-Promosi-Cashback-pada-OVO-dan-Go-Pay-Terhadap-PerilakuKonsumen-Mahasiswa-Fakultas-Ekonomi-dan-Bisnis-Universitas-Padjadjaran.pdf.

[3] Pambudi, R. D. 2019, Perkembangan Fintech di Kalangan Mahasiswa UIN, Harmony, No.4, Vol.2, 75-77, :https://journal.unnes.ac.id/sju/index.php/harmony/article/view/36456.

[4] Kusnawan, A., Silaswara, D., Andy, Sefung, T. 2019, Pengaruh Diskon pada Aplikasi eWallet Terhadap Pertumbuhan Minat Pembelian Impulsif Konsumen Milenial di Wilayah Tangerang, Jurnal Sains Manajemen, No.2, Vol.5, 138-152, :https://ejurnal.lppmunsera.org/index.php/SM/article/view/1861/1146. 
[5] Rofiah, S., Setiyadi, D. 2020, Pemilihan FinTech Payment Untuk Mahasiswa Menggunakan Fuzzy Technique for Order Preference by Similarity of Ideal Solution, BINA INSANI ICT JOURNAL, No.1, Vol.7, 13-22, :http://ejournalbinainsani.ac.id/index.php/BIICT/article/view/1341/1138.

[6] Kumala, I., Mutia, I. 2020, Pemanfaatan Aplikasi Dompet Digital Terhadap Transaksi Retail Mahasiswa, Seminar Nasional Riset dan Teknologi (SEMNAS RISTEK) 2020, 6469, :http://www.proceeding.unindra.ac.id/index.php/semnasristek/article/view/1118/216.

[7] Atriani, Permadi, L. A., Rinuastuti, B. H. 2020, Pengaruh Persepsi Manfaat dan Kemudahan Penggunaan Terhadap Minat Menggunakan Dompet Digital OVO, JSEH (Jurnal Sosial Ekonomi dan Humaniora), No.1, Vol.6, 54-61, : http://jseh.unram.ac.id/index.php/jseh/article/view/78/pdf.

[8] Muliaman D. Hadad, P. 2017, Financial Technology (Fintech) di Indonesia, Otoritas Jasa Keuangan, Kuliah Umum tentang FinTech - IBS, 2-3, :http://www.ibs.ac.id/img/doc/MDH\%20-\%20FinTech\%20IBS\%20June\%202017.pdf.

[9] Sulistyowati, R., Paais, L. S., Rina, R. 2020, Persepsi Konsumen Terhadap Penggunaan Dompet Digital, ISOQUANT: Jurnal Ekonomi, Manajemen dan Akuntansi, No.1, Vol.4, 19-20, :http://studentjournal.umpo.ac.id/index.php/isoquant/article/view/323/307.

[10] Suparno, P. 2017, Pembelajaran Bergaya PPR Untuk Meningkatkan Pengertian Dan Sikap Mahasiswa Bk Terhadap Statistika, Paul Suparno, No.2, Vol.21, 125-132, :https://repository.usd.ac.id/21464/1/4043_201712++Vol+212+03+Paul+Suparno+hal+1 25-132.pdf.

[11] Maysani, R., Pujiastuti, H. 2020, Analisis Kesulitan Mahasiswa Dalam Mata Kuliah Statistika Deskriptif, Al Khawarizmi: Jurnal Pendidikan dan Pembelajaran Matematika, No.1, Vol.4, 32-49, :https://jurnal.arraniry.ac.id/index.php/alkhawarizmi/article/view/6949/4429.

[12] Athoillah, M., Pramesti, W., P.H., E. M. 2020, Pelatihan Analisa Statistika Deskriptif Data Kependudukan Dengan Menggunakan Microsoft Excel Di Desa Gedangan Kecamatan Sidayu Kabupaten Gresik. J-ADIMAS (Jurnal Pengabdian kepada Masyarakat), No.1, Vol.8, $16 \quad-\quad 21, \quad$ :https://jurnal.arraniry.ac.id/index.php/alkhawarizmi/article/view/6949/4429.

[13] Ramadhanty, V. D., Permana, R. I., Fauzia, B. R., Rakhmawati, N. A. 2020, Analisis Faktor Penggunaan Dompet Digital di Kalangan Mahasiswa Surabaya, [Dataset], Zenodo, https://doi.org/10.5281/zenodo.4163662. 